\title{
GASIFICATION OF COAL CHAR IN A TWO-STAGE PRESSURIZED FLUIDIZED BED
}

\author{
JUN-ICHI KAWABATA, MidORI YUMIYAMA, YoNESHIRO \\ TAZAKI, SENJI HONMA, SHOHEI TAKEDA \\ AND HIROSHI YAMAGUCHI \\ Government Industrial Development Laboratory, Hokkaido, \\ Sapporo 061-01 \\ TADATOSHI CHIBA \\ Coal Research Institute, Hokkaido University, Sapporo 060 \\ KuNIO YOSHIDA \\ Engineering Research Institute, University of Tokyo, Tokyo 113
}

\begin{abstract}
A two-stage pressurized fluidized bed coal char gasification process has been developed. This process is one of the activities conducted under the "Sunshine Project" to provide coal conversion technology.

A partition disc was used to divide the fluidized bed into two stages, the first used as a combuster and the second as a gasifier. Coal char in the ash and sand bed was gasified by air and steam to produce low-heating value gases. Experimental data on carbon efficiency, exit gas composition, particle size distribution, etc. are reported in the present paper.
\end{abstract}

\section{Introduction}

A nationwide energy shortage, together with policy aiming at diversified energy sources, make the commercial production of synthetic fuels from coal vital to Japan's total supply of clean energy. In response to this need, the Ministry of International Trade and Industry (MITI) is conducting a research and development program under the name of "Sunshine Project" to provide technology that will permit the conversion of coal to synthetic fuels. MITI's program for the conversion of coal to gaseous fuels has been carried out by both the Government Laboratories belonging to MITI and several companies. At the Government Industrial Development Laboratory, Hokkaido, a process for low-heating value gasification in a two-stage pressurized fluidized bed has been designed, constructed and operated since 1975 .

To date results from many studies have been reported on coal gasification worldwide ${ }^{1,2)}$. There has been, however, little study of two-stage gasification in a fluidized bed which is divided by a horizontal perforated disc into two compartments. The purpose of this paper is to present the experimental results so far obtained.

\section{Experimental}

The reactor used in this study was designed from

Received October 9, 1979, Correspondence concerning this article should be addressed to J. Kawabata. the data obtained from a cold model test.

When a mixture of char and silica sand particles is fluidized the sand particles tend to sink to the lower part of the bed (the first stage), while the char particles float towards the upper part (the second stage). This tendency is clear at lower gas velocities and is accentuated by fitting a partition disc horizontally within the bed, forming a two-stage fluidized bed. If such segregating systems are employed in coal gasification, it becomes possible to use the first stage as a combuster for supplying process heat required for char gasification in the second stage. In addition, as only a small amount of char particles are fluidized within bulk sand particles in the first stage, they burn well by air without forming agglomerates.

The experimental apparatus, comprising the fluidized-bed reactor and auxiliary equipment, is shown in Fig. 1. The reactor was made of a $1400 \mathrm{~mm}$-long stainless steel tube and its inner wall surface was covered by firebricks with an inner diameter of $75 \mathrm{~mm}$. It was designed to stand $1300^{\circ} \mathrm{C}$ and 20 atmospheres pressure. As the gas distributor for the first-stage bed a perforated plate was used which has 2-mm holes in a triangular pitch. The horizontal disc dividing the bed into two stages was a perforated plate having opening ratio of 20 or $40 \%$ with $5-\mathrm{mm}$ holes, and it was situated $200 \mathrm{~mm}$ from the distributor.

The char particles were fed continuously via a screw feeder from a double lockhopper to the first stage of the pressurized fluidized bed, and the silica 


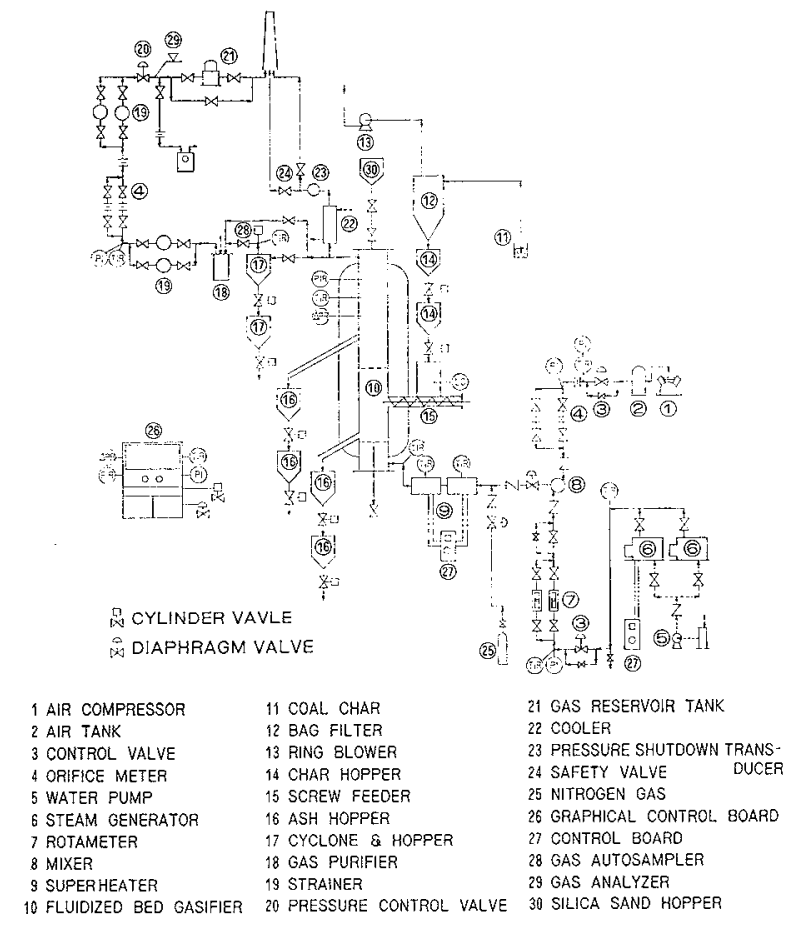

Fig. 1 Flowsheet of two-stage fluidized pressurized coal gasifier

Table 1 Properties of coal, coal char and silica sand employed in this study

\begin{tabular}{lccl} 
& $\begin{array}{c}\text { Taiheiyo } \\
\text { coal }\end{array}$ & $\begin{array}{c}500^{\circ} \mathrm{C} \\
\text { char }\end{array}$ & $\begin{array}{c}\text { Silica } \\
\text { sand }\end{array}$ \\
\hline Proximate analysis [wt \%] & & & \\
$\quad$ Moisture & 4.7 & 3.9 & \\
$\quad$ Ash & 10.2 & 15.7 & \\
$\quad$ Volatile matter & 45.9 & 21.0 & \\
$\quad$ Fixed carbon & 39.2 & 59.4 & \\
Ultimate analysis [dry \%] & & & \\
C & 68.2 & 67.4 & \\
$\mathrm{H}$ & 5.7 & 3.5 & \\
$\mathrm{O}$ & 14.8 & 12.4 & \\
$\mathrm{~N}$ & 1.0 & 0.8 & \\
$\mathrm{~S}$ & 0.1 & 0.1 & \\
Ash & 10.2 & 15.7 & \\
$\mathrm{H} . \mathrm{H} . \mathrm{V} .[\mathrm{Kcal} / \mathrm{Kg}]$ & 6487 & 6570 & \\
$u_{m f}[\mathrm{~cm} / \mathrm{sec}]$ & 21.5 & 15.0 & 27.0 \\
$\overline{d_{p}}[\mathrm{~mm}]$ & 0.45 & 0.44 & $0.50-0.71$ \\
$\rho_{b}\left[\mathrm{~g} / \mathrm{cm}{ }^{3}\right]$ & 0.65 & 0.38 & 1.3 \\
\hline
\end{tabular}

sand particles intermittently from a hopper on the top of the bed. The mixture of ash and fine unburnt char was discharged through an overflow pipe to another lockhopper. The height of the overflow was fixed at $100 \mathrm{~mm}$ from the partition disc. Ash produced and the silica sand falling down from the second to the first stage were drawn out together with the coaser residual char through a pipe attached just above the distributor.

The char particles used in this experiment were prepared by carbonizing Taiheiyo coal at $500^{\circ} \mathrm{C}$ in a $100 \mathrm{~mm}$ I.D. fluidized bed. Several properties of coal, char and silica sand used are summarized in

\begin{tabular}{rrrrrrr}
$\begin{array}{c}\text { Run } \\
\text { No. }\end{array}$ & $\begin{array}{r}T_{b 1} \\
{\left[{ }^{\circ} \mathrm{C}\right]}\end{array}$ & $\begin{array}{c}T_{b 2} \\
{\left[{ }^{\circ} \mathrm{C}\right]}\end{array}$ & $\begin{array}{c}P \\
{\left[\mathrm{~kg} / \mathrm{cm}^{2} \mathrm{G}\right]}\end{array}$ & $\begin{array}{c}\mathrm{Air} \\
{\left[\mathrm{Nm}^{3} / \mathrm{hr}\right]}\end{array}$ & $\begin{array}{c}\text { Steam } \\
{[\mathrm{kg} / \mathrm{hr}]}\end{array}$ & $\begin{array}{c}\mathrm{Char} \\
{[\mathrm{kg} / \mathrm{hr}]}\end{array}$ \\
\hline 18 & 950 & 820 & 3.1 & 4.8 & 3.6 & 2.04 \\
19 & 1000 & 870 & 3.1 & 4.8 & 3.6 & 1.50 \\
22 & 900 & 780 & 3.0 & 4.7 & 3.0 & 2.16 \\
23 & 950 & 810 & 3.0 & 4.7 & 3.0 & 2.57 \\
24 & 1000 & 820 & 3.0 & 4.7 & 3.0 & 2.35 \\
25 & 950 & 820 & 3.0 & 4.7 & 2.7 & 1.93 \\
26 & 950 & 820 & 3.0 & 4.7 & 3.6 & 1.67 \\
27 & 880 & 800 & 3.0 & 4.7 & 2.8 & 2.70 \\
28 & 880 & 835 & 3.0 & 4.5 & 2.8 & 2.67 \\
30 & 880 & 810 & 3.0 & 4.7 & 3.0 & 2.45 \\
31 & 950 & 860 & 3.0 & 5.6 & 2.4 & 2.40 \\
34 & 1000 & 930 & 3.0 & 5.6 & 3.4 & 2.20 \\
35 & 1050 & 950 & 3.0 & 6.1 & 2.0 & 2.32 \\
42 & 1000 & 955 & 3.0 & 4.7 & 3.2 & 1.35 \\
46 & 1050 & 980 & 3.0 & 5.6 & 2.4 & 1.80
\end{tabular}

Table 1.

Steam produced by an electric boiler was mixed with air and fed into the first stage of the bed at about $500^{\circ} \mathrm{C}$ through a preheater. Gas product was metered and analyzed after cleaning by both a cyclone and a water tank. The reaction temperature was controlled by adjusting the feed rate of char particles. In each experimental run char particles were fed after setting the pressure in the reactor at $2 \mathrm{~kg} / \mathrm{cm}^{2} \mathrm{G}$. Then, both temperature and pressure in the reactor were gradually increased to specified values. Pressure was regulated by a diaphragm controller.

\section{Results and Discussion}

Representative experimental results are listed in Table 2. The following three kinds of conversion are defined and shown in the table.

carbon conversion, $C_{c}$

(CO) measured in exit gas

$=\frac{(\mathrm{CO}) \text { calculated from char fed }}{(\mathrm{CO})}$

where $(\mathrm{CO})$ concentration in the exit gas is assumed to be produced only from the carbon-steam reaction.

heat conversion, $H_{c}$

$$
=\frac{\left(\begin{array}{l}
\text { heating value of } \\
\text { gas produced }
\end{array}\right)\left(\frac{\text { amount of gas }}{\text { unit char fed }}\right)}{\text { (heating value of char, } 6570 \mathrm{kcal} / \mathrm{kg} \text { ) }}
$$

and

steam conversion, $S_{c}$

amount of steam consumed

$$
\left(\begin{array}{l}
\text { amount of steam fed }+ \text { water contained in char } \\
+ \text { water assumed to be produced from combus- } \\
\text { tion of } \mathrm{H}_{2} \text { in char }
\end{array}\right)
$$

where the steam consumption was calculated on the assumption that the water-gas reaction proceeds at equilibrium.

Figure 2 shows the comparison of $\mathrm{CH}_{4}, \mathrm{CO}, \mathrm{H}_{2}$ and $\mathrm{CO}_{2}$ concentrations in both stages of the bed. These 
Table 2 Representative experimental results

\begin{tabular}{|c|c|c|c|c|c|c|c|c|c|c|c|c|c|c|c|c|}
\hline \multirow{2}{*}{$\begin{array}{l}\text { Produced } \\
\text { gas } \\
{\left[\mathrm{Nm}^{3} / \mathrm{hr}\right]}\end{array}$} & \multicolumn{2}{|c|}{$\begin{array}{c}\mathrm{CH}_{4} \\
{[\mathrm{~mol} / \mathrm{hr}]}\end{array}$} & \multicolumn{2}{|c|}{$\underset{[\mathrm{mol} / \mathrm{hr}]}{\mathrm{CO}}$} & \multicolumn{2}{|c|}{$\begin{array}{c}\mathrm{H}_{2} \\
{[\mathrm{~mol} / \mathrm{hr}]}\end{array}$} & \multicolumn{2}{|c|}{$\begin{array}{c}\mathrm{CO}_{2} \\
{[\mathrm{~mol} / \mathrm{hr}]}\end{array}$} & \multicolumn{2}{|c|}{$\begin{array}{c}C_{c} \\
{[-]}\end{array}$} & \multicolumn{2}{|c|}{$\begin{array}{c}H_{c} \\
{[-]}\end{array}$} & \multicolumn{2}{|c|}{$\begin{array}{c}S_{c} \\
{[-]}\end{array}$} & \multicolumn{2}{|c|}{$\begin{array}{c}H_{h} \\
{\left[\mathrm{Kcal} / \mathrm{Nm}^{3}\right]}\end{array}$} \\
\hline & $1 \mathrm{st}$ & 2nd & 1 st & 2nd & Ist & 2nd & Ist & 2nd & 1 st & $2 \mathrm{nd}$ & $1 \mathrm{st}$ & 2nd & 1st & 2nd & 1st & 2nd \\
\hline 6.3 & 3.0 & 3.4 & 23.5 & 24.1 & 45.0 & 50.0 & 46.1 & 47.7 & 0.25 & 0.26 & 0.40 & 0.43 & $\longrightarrow$ & - & 863 & 912 \\
\hline 6.3 & 2.1 & 2.0 & 18.1 & 26.7 & 35.2 & 46.9 & 44.5 & 46.3 & 0.26 & 0.38 & 0.45 & 0.55 & - & - & 698 & 856 \\
\hline 6.7 & 5.6 & 3.9 & 24.8 & 25.1 & 48.8 & 53.2 & 50.8 & 50.8 & 0.23 & 0.23 & 0.45 & 0.43 & 0.36 & 0.52 & 956 & 916 \\
\hline 7.6 & 7.1 & 5.1 & 34.1 & 29.9 & 72.4 & 67.4 & 60.0 & 56.1 & 0.24 & 0.21 & 0.50 & 0.45 & 0.10 & 0.40 & 1100 & 1008 \\
\hline 7.6 & 5.8 & 4.8 & 34.9 & 29.6 & 74.9 & 65.3 & 57.3 & 53.4 & 0.27 & 0.23 & 0.53 & 0.48 & 0.01 & 0.41 & 1075 & 977 \\
\hline 6.9 & 2.5 & 3.4 & 20.8 & 27.6 & 41.4 & 56.5 & 44.4 & 51.0 & 0.25 & 0.33 & 0.48 & 0.58 & - & - & 762 & 922 \\
\hline 7.2 & 2.7 & 4.0 & 19.7 & 28.1 & 45.1 & 61.1 & 45.1 & 51.9 & 0.15 & 0.22 & 0.33 & 0.41 & 0.38 & 0.46 & 811 & 1006 \\
\hline 7.1 & 3.2 & 4.1 & 27.8 & 27.3 & 60.9 & 61.2 & 54.6 & 54.8 & 0.20 & 0.20 & 0.38 & 0.39 & 0.27 & 0.34 & 943 & 967 \\
\hline 7.6 & 3.9 & 5.1 & 27.9 & 30.5 & 65.4 & 70.1 & 54.9 & 56.6 & 0.22 & 0.24 & 0.46 & 0.49 & 0.25 & 0.38 & 972 & 1041 \\
\hline 8.9 & 5.5 & 4.7 & 44.4 & 47.8 & 70.1 & 71.9 & 54.9 & 56.1 & 0.35 & 0.37 & 0.57 & 0.58 & 0.26 & 0.44 & 1022 & 1029 \\
\hline 8.5 & 5.2 & 4.1 & 42.2 & 43.0 & 61.1 & 65.6 & 53.4 & 55.5 & 0.37 & 0.38 & 0.57 & 0.57 & 0.23 & 0.29 & 977 & 974 \\
\hline 9.0 & 3.6 & 3.6 & 44.1 & 48.0 & 58.8 & 62.1 & 58.4 & 57.7 & 0.36 & 0.39 & 0.51 & 0.54 & 0.00 & 0.28 & 867 & 909 \\
\hline 7.9 & 2.1 & 3.9 & 19.0 & 34.9 & 30.5 & 58.5 & 48.9 & 54.0 & 0.21 & 0.39 & 0.38 & 0.60 & 0.09 & 0.10 & 562 & 905 \\
\hline
\end{tabular}

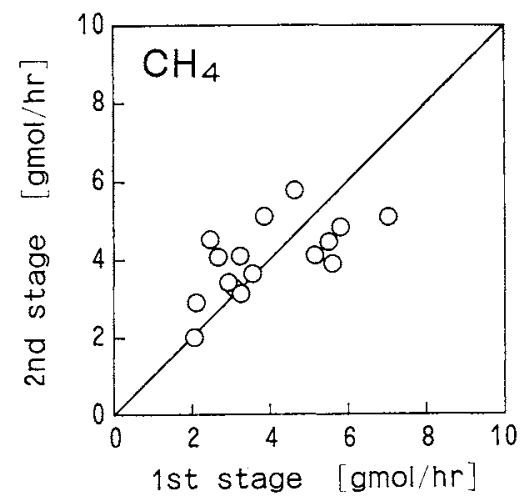

(a)

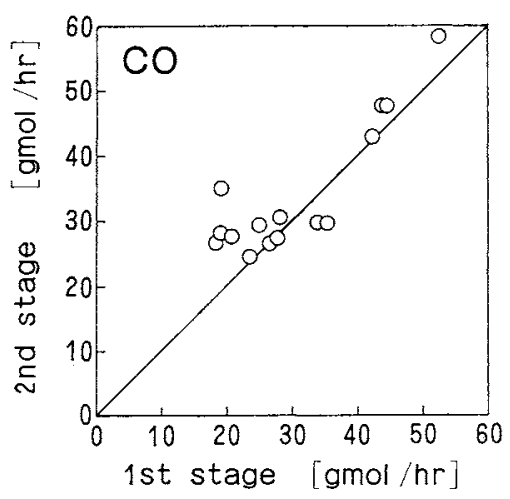

(b)

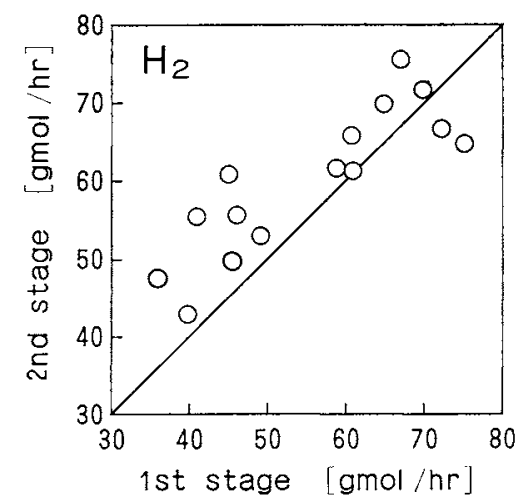

(c)

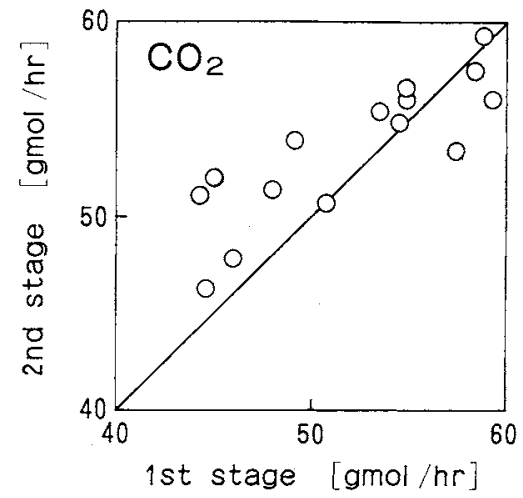

(d)

Fig. 2 Comparison of $\mathrm{CH}_{4}, \mathrm{CO}, \mathrm{H}_{2}$ and $\mathrm{CO}_{2}$ concentration in both stages

values can be calculated by assuming the amount of nitrogen to be constant in both stages. Little difference of $\mathrm{CH}_{4}$ concentrations in both stages suggests that only volatile matter of char decomposes to produce $\mathrm{CH}_{4}$ in the first stage. Also, increased concentrations of $\mathrm{H}_{2}, \mathrm{CO}$ and $\mathrm{CO}_{2}$ in the second stage suggest the progress of gasification in the stage as well as in the first stage. This becomes clearer in terms of $C_{c}, H_{c}$ and $S_{c}$ as illustrated in Fig. 3. Although the conversion change in the second stage seems much less than expected, further gasification can be obtained by increasing the height of the overflow pipe to give a longer mean residence time of char in the second stage.

A relationship between the heating value of gas produced and the feed rate of char is shown in Fig. 4. It is shown that heating value increases with char feed rate. However, ash agglomeration also occurs more frequently at higher char feed rates. There should be an optimum ratio of sand to char particles to achieve the highest possible heating value of gas without formation of agglomerates.

The heat required for gasification in the second stage is expected to be given by the heat of combus- 


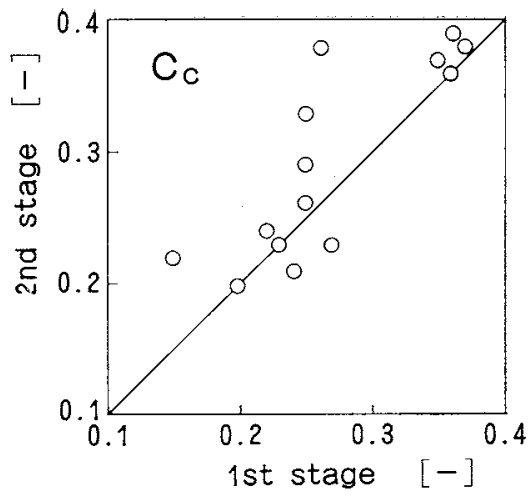

(a)

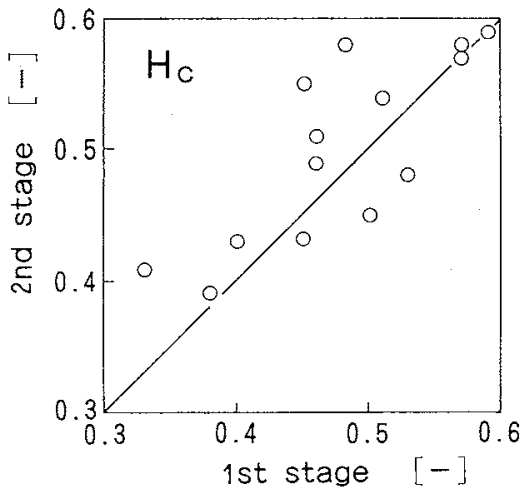

(c)

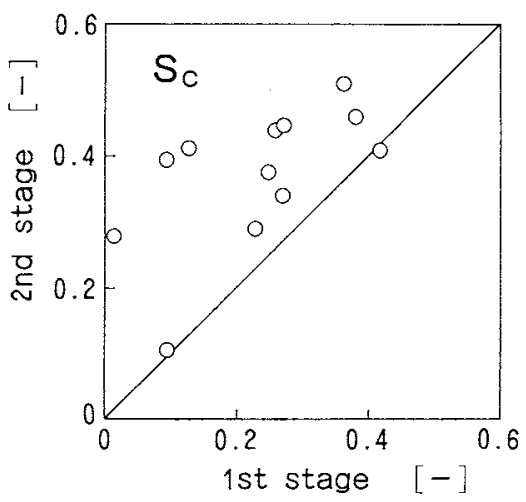

(c)

Fig. 3 Comparison of $C_{c}, H_{c}$ and $S_{c}$ in both stages

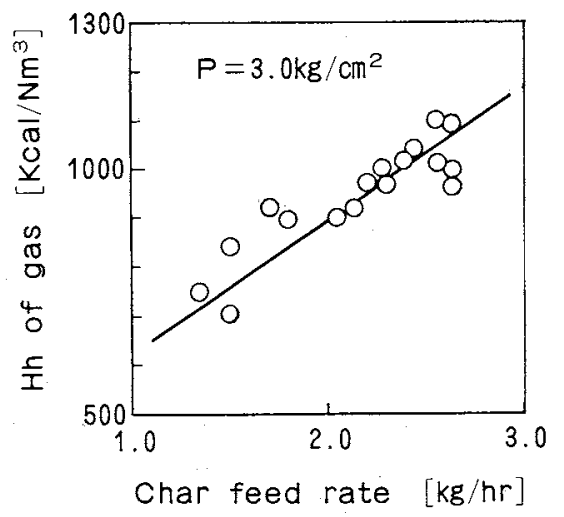

Fig. 4 Relationship between char feed rate and heating value of gas produced

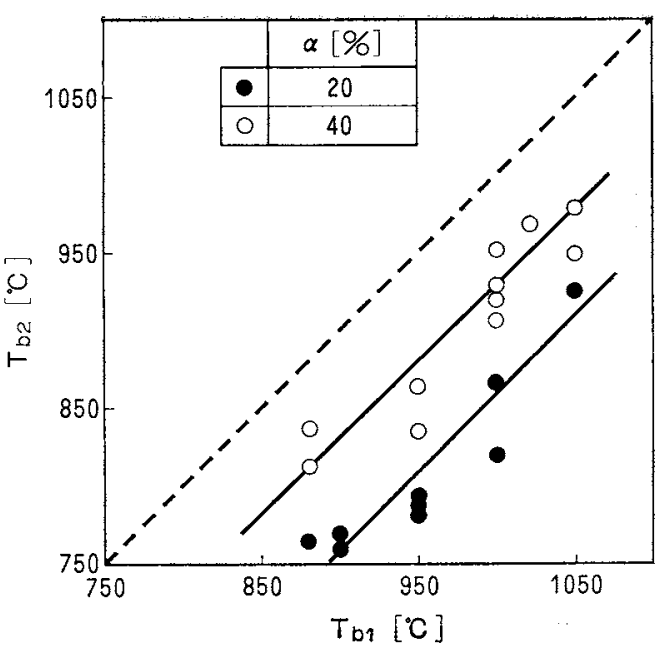

Fig. 5 Bed temperature of both stages vs. opening ratio of partition dise

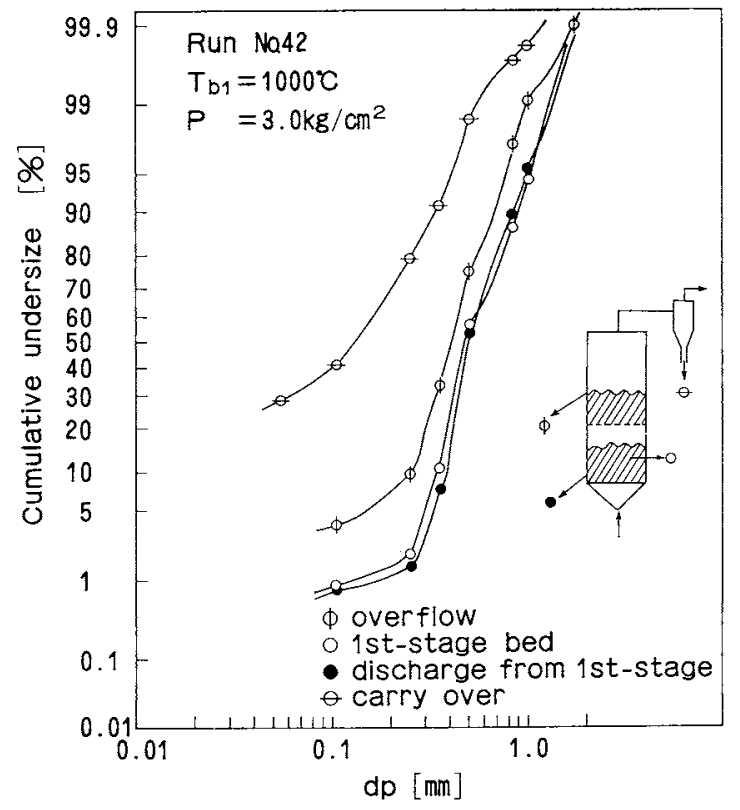

Fig. 6 Size distribution of particles taken at various points

tion of char in the first stage. It had already been found in the cold model test that the temperature difference between the two stages is much affected by the opening ratio of the partition disc. The data from the hot model experiment indicate similar results, as shown in Fig. 5.

Figure 6 shows the size distribution of particles taken from various positions in this process, and the results of proximate analysis for these particles except for silica sand are summarized in Table 3. Since fixed carbon content in the particles from the overflow pipe seems quite large, efforts toward improving carbon efficiency must be made by increasing reaction temperature and char residence time.

There were no tar problems, because char was the raw material in the present experiment, but a con- 
Table 3 Proximate analysis [wt $\%]$

\begin{tabular}{lccrc}
\multicolumn{1}{r}{ Samples } & Moisture & $\begin{array}{c}\text { Volatile } \\
\text { matter }\end{array}$ & $\begin{array}{c}\text { Fixed } \\
\text { carbon }\end{array}$ & Ash \\
\hline Overflow & 0.16 & 2.91 & 18.76 & 78.17 \\
1st-stage bed & 0.04 & 0 & 5.37 & 94.59 \\
Discharge from & & & & \\
$\quad$ 1st stage & 0.25 & 3.52 & 9.11 & 87.12 \\
Carry over & 1.55 & 5.41 & 38.89 & 54.15 \\
& \multicolumn{5}{c}{ (Run No. 42) }
\end{tabular}

siderable amount of dust was generated. Figure 7 shows the relationship between carry-over and gas velocity including the pressure effect, where the abscissa represents the force acting on unit volume of a single particle. It is found that pressurization causes an increase of fine dust elutriation.

\section{Conclusion}

Two-stage pressurized fluidized gasifier was developed to produce low-heating value gas from coal char. The two stages consist of a combuster to burn a part of the char to provide process heat and a gasifier to convert the char to gaseous fuels.

The conversions increased in the second stage, estimated on the basis of carbon, steam and heat balances, suggesting that the process is basically promising although some design improvements will be necessary in the future, as pointed out in this paper.

\section{Acknowledgments}

This research was financially supported by a Grant-in-Aid for the Sunshine Project from the Ministry of International Trade and Industry, Japan.

We are indebted to Drs. M. Ishida and S. Mori for their helpful suggestions.

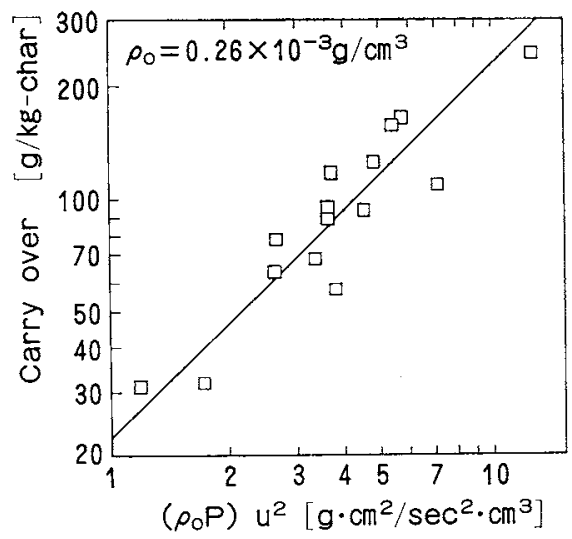

Fig. 7 Relationship between carryover and gas velocity

\section{Nomenclature}

$C_{c} \quad=$ carbon conversion defined by Eq. (1)

$d_{p} \quad=$ particle diameter

$H_{c} \quad=$ heat conversion defined by Eq. (2)

$H_{h} \quad=$ higher heating value of gas, HHV

$P \quad=$ operating pressure

$S_{c} \quad=$ steam conversion defined by Eq. (3)

$T_{b} \quad=$ bed temperature

$u_{m f} \quad=$ minimum fluidization velocity

$u \quad=$ superficial gas velocity

$\alpha \quad=$ opening ratio of partition disc

$=$ density of gas produced

$\rho_{b} \quad=$ bulk density of solid particles $\quad\left[\mathrm{g} / \mathrm{cm}^{3}\right]$

\section{Literature Cited}

1) Ikeda, Y., H. Kimura and Y. Sakanishi: Kagaku Kögaku, 38, 697 (1974).

2) Kimura, H. and S. Fujii: "Sekitan Kagaku to Kōgyō (Coal Chemistry and Industry)", Sankyo Pub. Co. Ltd. 